\title{
A Cerebral Palsy Student's University Reading Lived Experience
}

\author{
Philip Wee Poh Heng \\ Universiti Pendidikan Sultan Idris \\ email: philip.singlish@gmail.com
}

\begin{abstract}
This article presents a transcendental phenomenological study of the indigenous meanings of the reading challenges of a student with cerebral palsy. An understanding of the phenomenon could contribute to the conversation on academic literacy support for struggling readers, including those with medical and/or physical issues.
\end{abstract}

Keywords: transcendental phenomenology, cerebral palsy (CP), reading comprehension

\section{INTRODUCTION}

Cerebral Palsy (CP) results from an attack on the developing central nervous system, with the degree of impairment depending on individual factors, such as the location, size, nature/severity, and timing of the lesion (Blondis, 2004). Apart from motor impairments, brain dysfunction may also result in cognitive problems, which include learning disorders, such as reading difficulties. CP may well present very different profiles of instructional needs (Kedia, et al., 2014). Variations could also be in the form of those who are able to learn to read and write, as well as those who are not. As such, the reading experience may differ from one $\mathrm{CP}$ case to another. With this proviso, the research problem is stated. To grasp the reading problem of the university student with $\mathrm{CP}$ in this study, an appreciation of the context could be useful. Studies in Malaysia show that 3 out of every 10 students lack the English proficiency needed at university level (for example, Isarji Sarudin et al., 2008). Apart from her medical and physical issues, the research participant also had issues with university reading.

"An emic perspective attempts to capture the subject's indigenous meanings of real world events" (Yin, 2011). The purpose of the study was to explore and describe the emic of the student with $\mathrm{CP}$ who struggled with reading while studying at a university in Malaysia. In order to explore and describe the emic of the university student with $\mathrm{CP}$, the theoretical framework consisting of reading skills and strategies (Kintsch 2004), social interaction with instructors and peers (Reznitskaya et al. 2007), and motivation to read (Mendler, 2000) was used.

\section{Research Questions}

1. What is the textual description of the struggling reader with $\mathrm{CP}$ at the university?

2. What is the structural description of the struggling reader with $\mathrm{CP}$ at the university? 
3. What is the essence of the lived experience of the struggling reader with $\mathrm{CP}$ at the university?

\section{METHODOLOGY}

Because the aim was to explore and describe the phenomenon, the transcendental phenomenological approach was selected. Ary et al. (2006) supported this research design when the aim is to determine the essence of the experience as perceived by the subject(s). In order to enhance validity and reliability of the study, triangulation was utilized from three data sources: Interviews, the Motivation for Reading Questionnaire (MRQ) by Wigfield and Guthrie (1995), and Student-Created Drawings.

\section{Site of the Research}

The study was conducted at a 10,000-strong private university in Malaysia. All instruction is conducted in the English language medium.

\section{Research Participant}

A participant in a phenomenological study is chosen because she has been through the experience of being investigated and can share his or her thoughts and feelings about it (Ary et al. 2006). Jessie (a pseudonym for confidentiality purpose) was selected by purposeful sampling, based on Survey of Reading Strategies, or SORS (Mokhtari and Reichard, 2002). English was not her lingua franca, having previously studied English only as a classroom subject. As a CP student, the findings of the study have this limitation for the purpose of generalization. At the time of this study, Jessie had already struggled for eight years at the university with limited success, while undertaking a degree program in English Language and Communication.

\section{Data Collection Instruments}

\section{Interview Guide}

The open-ended primary multiple, in-depth interview questions included: "What is your experience with reading texts used at the university?" "Describe your mental image of the struggling reader at the university." "What feelings come to mind?" "What meaning does it have in your university life?" "Draw an image of the struggling reader at the university and tell me what each symbol means."

\section{Motivation for Reading Questionnaire}

The MRQ responses were scored by using the self-scoring method. The researcher subsequently used the responses for discussion and clarification. This researcher ensured that Jessie also benefited from the exercise by providing answers regarding questions that she might have about her motivation to read.

Student-Created Drawings 
Jessie was invited to draw pictures to express her thoughts and feelings as candidly as possible with regards to the kinds of situations that she, as a student, typically found herself in when engaging in university reading university.

\section{Validity and Reliability}

\section{Bracketing}

This is a process of setting aside one's beliefs, feelings and perceptions to be more open or faithful to the phenomenon (Streubert \& Carpenter 1999). As the human instrument, this researcher avoided personal bias as much as possible. Still, as Maxwell (2005) pointed out, bias cannot be completely omitted in qualitative research. In order to further enhance credibility and confirmability, triangulation using data collected from three sources - all from the same research participant, and not from other sources, thus validating the findings (Ary et al. 2006).

\section{Reliability}

Reliability controls consisted of using the research participant as Co-Researcher to provide member-checking of her own interview transcripts. A Research Assistant (M.Ed) was also used to verify that the transcripts were accurate and consistent with the audio-recordings.

\section{Data Analysis}

Using the modified method by Moustakas (1994), which employs the process of reduction, full descriptions of the experience of the phenomenon were taken from the verbatim transcripts of the interviews. The significant statements, from which the nonrepeating and non-overlapping units of meaning were selected, yield the invariant meanings. The textural description and the structural description of Jessie's experience were produced. Finally, a composite textural-structural description of the experience was constructed.

\section{RESULTS}

\section{Interviews}

From the interviews, the significant statements were identified, from which the nonrepeating and non-overlapping units of meaning were selected, yielding the invariant meanings.

Table 1: Interview Questions (Part 1)

\begin{tabular}{|c|l|l|}
\hline JESSIE & \multicolumn{1}{|c|}{ SIGNIFICANT STATEMENTS } & RESEARCHER'S ANALYSIS \\
\hline Q1 & $\begin{array}{l}\text { What is your experience with reading texts used } \\
\text { at the university? }\end{array}$ & $\begin{array}{l}\text { My school did not prepare me to read at the } \\
\text { university. }\end{array}$ \\
\hline SS1 & $\begin{array}{l}\text { lacked Cognitive Academic } \\
\text { Language Proficiency (CALP) } \\
\text { (T) }\end{array}$ \\
\hline
\end{tabular}




\begin{tabular}{|c|c|c|}
\hline SS2 & The textbooks are difficult to understand. & frustration text readability $(\mathrm{T})$ \\
\hline SS3 & At the university, I have to read so much. & $\begin{array}{l}\text { lacked CALP } \\
(\mathrm{T})\end{array}$ \\
\hline SS4 & $\begin{array}{l}\text { The sentences are very long and hard to } \\
\text { understand. }\end{array}$ & $\begin{array}{l}\text { frustrational readability } \\
(\mathrm{T})\end{array}$ \\
\hline SS5 & $\begin{array}{l}\text { The chapters are very long, } 20-40 \text { pages ... } \\
\text { takes long time to finish. }\end{array}$ & $\begin{array}{l}\text { frustrational readability } \\
(\mathrm{T})\end{array}$ \\
\hline SS6 & $\begin{array}{l}\text { I don't know why the textbook meaning of the } \\
\text { terms is so different from the dictionary } \\
\text { meaning. }\end{array}$ & $\begin{array}{l}\text { frustrational readability } \\
(\mathrm{T})\end{array}$ \\
\hline SS7 & $\begin{array}{l}\text { I do not read before lectures because I need the } \\
\text { time to read the subjects already covered earlier. }\end{array}$ & $\begin{array}{l}\text { lacked CALP } \\
(\mathrm{T})\end{array}$ \\
\hline Q2 & $\begin{array}{l}\text { Describe your mental image of the struggling } \\
\text { reader at the university. }\end{array}$ & \\
\hline
\end{tabular}

\section{Table 1: Interview Questions (Part 2)}

\begin{tabular}{|c|c|c|}
\hline JESSIE & $\begin{array}{l}\text { SIGNIFICANT STATEMENTS } \\
\end{array}$ & RESEARCHER'S ANALYSIS \\
\hline SS8 & The reading is like endless ... so much to read & $\begin{array}{l}\text { experienced stress } \\
\text { (S) }\end{array}$ \\
\hline SS9 & Must pass so many exams & $\begin{array}{l}\text { experienced stress } \\
\text { (S) }\end{array}$ \\
\hline Q3 & What feelings come to your mind? & \\
\hline SS10 & $\begin{array}{l}\text { It is usually quite stressful for me - many } \\
\text { difficult words; ... in school, the word has one } \\
\text { meaning, but now in uni the same word have } \\
\text { different meaning. }\end{array}$ & $\begin{array}{l}\text { lacked CALP } \\
(\mathrm{T}) \\
\text { experienced stress } \\
(\mathrm{S})\end{array}$ \\
\hline SS11 & I feel no one around to help me to read. & $\begin{array}{l}\text { experienced loneliness } \\
\text { (S) }\end{array}$ \\
\hline SS12 & I am a slow reader, but I'm not stupid. & $\begin{array}{l}\text { experienced hurt } \\
(\mathrm{S})\end{array}$ \\
\hline Q4 & $\begin{array}{l}\text { What meaning does it have in your university } \\
\text { life? }\end{array}$ & \\
\hline SS14 & $\begin{array}{l}\text { When I finish my studies, I hope I never read } \\
\text { again because I have the thick, thick books I } \\
\text { have to read every semester ... cannot stop } \\
\text { reading. }\end{array}$ & $\begin{array}{l}\text { non-stop reading, fatigue, and } \\
\text { unable to do much else } \\
\text { (T) }\end{array}$ \\
\hline SS15 & I am a slow reader, but I'm not stupid. & $\begin{array}{l}\text { possessed self-efficacy } \\
(\mathrm{S})\end{array}$ \\
\hline Q5 & $\begin{array}{l}\text { Do you think you are a motivated reader in the } \\
\text { English language? If not, why not? }\end{array}$ & \\
\hline SS16 & $\begin{array}{l}\text { I get very little bit, just comments on my } \\
\text { assignments, but what for, all over already, the } \\
\text { marks all given, and cannot improve next time. }\end{array}$ & $\begin{array}{l}\text { de-motivated } \\
\text { (S) }\end{array}$ \\
\hline SS17 & I just keep quiet and shake my head in class. & $\begin{array}{l}\text { de-motivated; avoidance } \\
\text { (S) }\end{array}$ \\
\hline
\end{tabular}




\begin{tabular}{|l|l|l|c|}
\hline \multicolumn{1}{|c|}{ Constructs } & Jessie & \multicolumn{1}{c|}{ Constructs } & Jessie \\
\hline $\begin{array}{l}\text { 1. Family } \\
\text { Involvement }\end{array}$ & Negative & 4. Self-Perception & Negative \\
\hline 2. Grade Perception & Positive & $\begin{array}{l}\text { 5. Desire for } \\
\text { Compliments }\end{array}$ & Positive \\
\hline 3. Reading Interest & Negative & 6. Social Interaction & Positive \\
\hline
\end{tabular}

Table 1: Interview Questions (Part 3)

\begin{tabular}{|c|c|c|}
\hline JESSIE & SIGNIFICANT STATEMENTS & RESEARCHER'S ANALYSIS \\
\hline Q6 & $\begin{array}{l}\text { In what ways were your parents involved in } \\
\text { your university reading? }\end{array}$ & \\
\hline SS18 & No. They're always busy. & $\begin{array}{l}\text { lacked parental involvement } \\
\text { (T) }\end{array}$ \\
\hline Q7 & $\begin{array}{l}\text { In what ways were your lecturers involved in } \\
\text { your university reading? }\end{array}$ & \\
\hline SS21 & $\begin{array}{l}\text { The lecturer should explain the special } \\
\text { meanings of the words and phrases. Then I } \\
\text { don't need to find and find (keep searching) for } \\
\text { the correct meaning. That's why I find my } \\
\text { reading is so slow and tiring. }\end{array}$ & $\begin{array}{l}\text { course instructor unhelpful; } \\
\text { needed scaffolding and/or use of } \\
\text { schema to understand better } \\
\text { (T) }\end{array}$ \\
\hline Q8 & $\begin{array}{l}\text { How do you feel when you discussed your } \\
\text { readings with your lecturers/peers? }\end{array}$ & \\
\hline SS26 & If discuss, I can listen and understand. & $\begin{array}{l}\text { preferred co-op learning; learning } \\
\text { style: aural } \\
\text { (T) }\end{array}$ \\
\hline SS28 & $\begin{array}{l}\text { I hate reading alone. I prefer to attend group } \\
\text { study, then I can listen and discuss, so can } \\
\text { understand. }\end{array}$ & $\begin{array}{l}\text { preferred co-op learning; learning } \\
\text { style: aural } \\
\text { (T) }\end{array}$ \\
\hline SS29 & $\begin{array}{l}\text { I think many of the students don't want me in } \\
\text { their group because maybe they think I will slow } \\
\text { them down or they will get less marks because of } \\
\text { me. I don't blame them, but it makes me feel } \\
\text { unwanted and unhappy. How do I feel? Sure, } \\
\text { what ... unwanted! I feel useless and angry } \\
\text { because it is unfair ... who wants to be } \\
\text { handicapped? }\end{array}$ & $\begin{array}{l}\text { needed reading support; peers } \\
\text { lacked orientation to cooperative } \\
\text { learning } \\
\text { (T) } \\
\text { felt resentment and self- } \\
\text { consciousness of her handicap } \\
\text { (S) }\end{array}$ \\
\hline
\end{tabular}

* Significant Statements (SS); Transcendental Description (T); Structural Description (S)

Table 2: Motivation for Reading Questionnaire (MRQ) Responses 
Jessie's MRQ response on Family Involvement corresponded with her interview statement (SS18). Her Grade Perception was positive, although her actual CGPA was border-line and she perceived that she was not 'stupid' (SS15, 26); however, she mentioned that she 'must pass so many exams' which could imply that much reading (or rote learning) was a regular feature at the university (SS9). Her MRQ response to Reading Interest of university texts confirmed her negative outlook on this score (SS8, $10,14)$. Her Self-Perception where university reading was concerned, according to the MRQ, was negative; this corresponded with her interview statement (SS1-8, 17). On the Desire for Compliments, her MRQ indicated a positive response; however, at the interviews, Jessie indirectly expressed the desire for some form of affirmation for her efforts (SS16). Her MRQ response for Social Interaction was highly positive, which tallied with the overall interview comments (SS26, 28), although she was disappointed whenever those of her peers turned her away from joining their groups for reason of achieving better grades without her involvement, which she felt was because of her CP handicap (SS11, 12, 29).

\section{Drawings}

The overall impression of the first drawing was that the person was overwhelmed by the reading task. The books looked rather thick. Jessie explained that the large question mark was intended to express the endless questions she had in attempting to make sense of the contents. The fire surrounding the books expressed her strong wish that those books would someday be burned to erase her horrendous university reading experience.

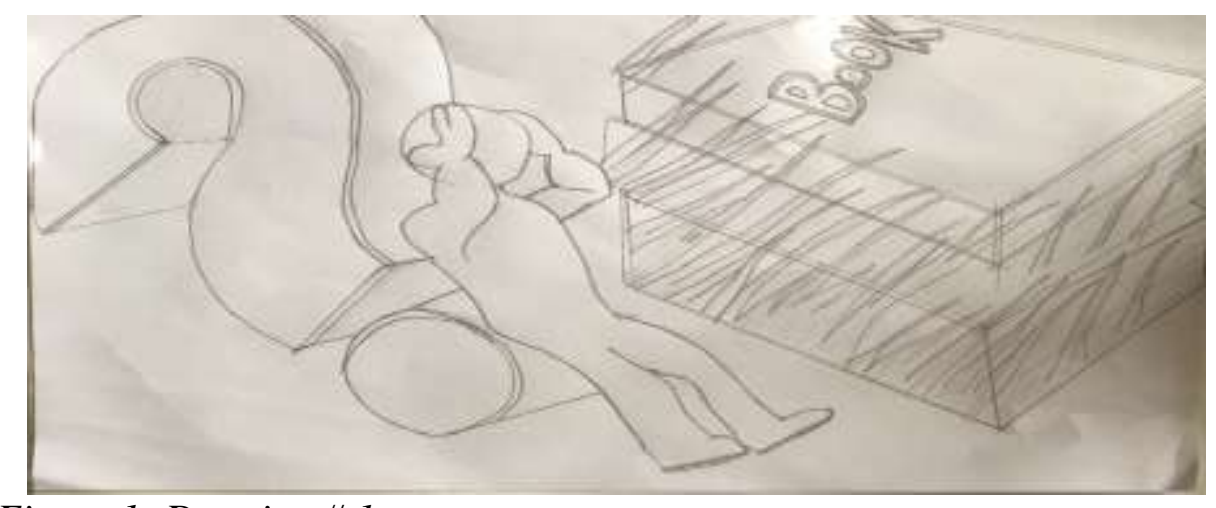

Figure 1: Drawing \# 1

In her second drawing, she utilised an image of a turtle to depict herself as she navigated slowly and laboriously through the course materials endlessly. Jessie also thought that a turtle would aptly describe her physical disability, being a CP patient, always tired (through the paddling). In her explanation, she pointed out that she was always conscious of her physical handicap. 


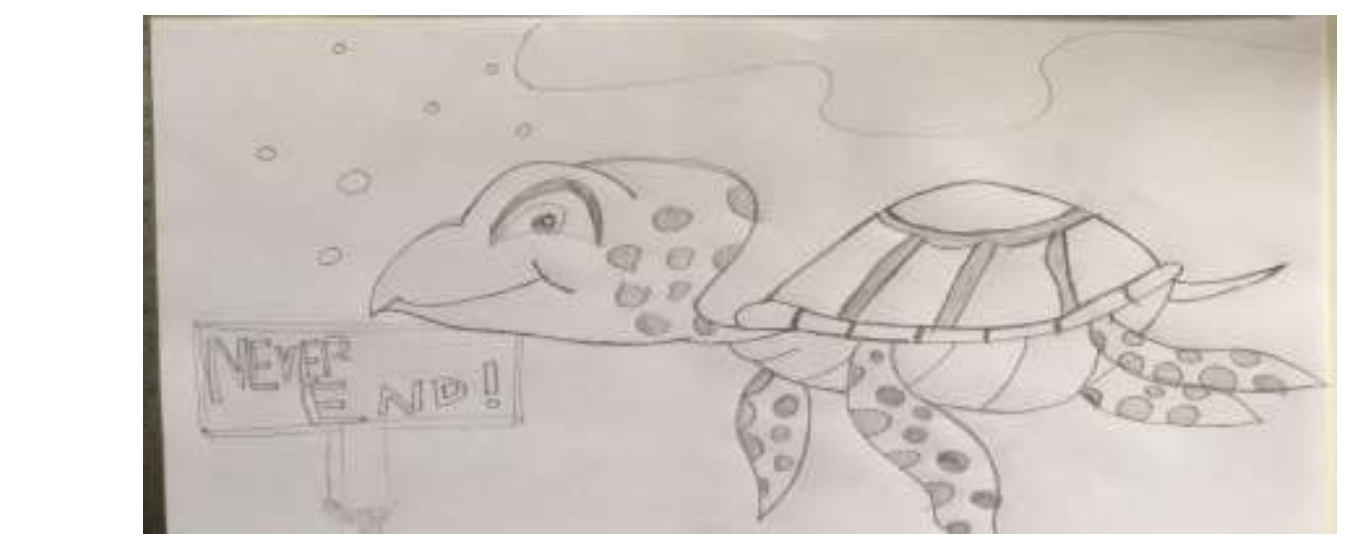

Figure 2: Drawing \# 2

These drawings were consistent with the interview and MRQ findings. First, the selected course materials assigned by the university required CALP, or academic literacy, which Jessie obviously lacked. Second, her CP affliction was an additional disadvantage in her case, especially in restricting her mobility to participate more easily in social (with lecturers and her peers in the cohort) reading activities, such as in cooperative learning events. Significantly, reading alone was depicted in both her drawings because only one person/turtle was featured!

Research Question 1: What is the textual description of the struggling reader with $C P$ at the university?

The research participant who has $\mathrm{CP}$ continually struggled with her university reading because of her lack in the area of academic literacy, or CALP. She lacked the reading skills, reading rate, and reading strategies that were needed to grasp and appreciate the relevant text-related nuances. As such, while she considered herself as intelligent ("I am a slow reader, but I'm not stupid."), she struggled to achieve good grades. Furthermore, because her reading rate was slow, she had very little respite in-between her readings. The experience was aggravated by the lack of text readability, as inferred by her complaint of difficulty in the vocabulary (unfamiliar words or words with 'unusual' meanings) and density (long sentences, chapters, lack of illustrations). Inevitably, Jessie singled out her CP condition as a handicap she could do without because it limited her opportunities for reading interaction, especially with her peers.

Research Question 2: What is the structural description of the struggling reader with $\mathrm{CP}$ at the university?

Like most other students at the university, Jessie had to tackle the denser and heavy load of reading. However, being afflicted with $\mathrm{CP}$ limited her mobility, and consequently access to cooperative learning with her peers as well as with her course instructors outside lecture sessions, Jessie often had to cope with her reading struggles alone and at home. Jessie's limitations in social reading caused her to be frustrated, which not infrequently led her to contemplate suicide. On the other hand, the MRQ showed that despite abating motivation to read, she rationalized so long as she passed her examinations, she was satisfied. She added that her drawing that showed the 
tortoise paddling continually meant that she would keep trying to understand the reading materials by staying up late, instead of giving up and sleeping.

Research Question 3: What is the essence of the lived experience of the struggling reader with $C P$ at the university?

Results from all three data sources (the multiple in-depth interviews, MRQ, and drawings) concurred that Jessie was indeed a struggling reader. Since CALP was lacking, she sought, with little success, the reading support from course instructors and her peers that were not forthcoming. Jessie's emic is her reality: she has CP and she struggled to read the prescribed reading materials. As a result, Jessie had to cope with a sense of inferiority. Often she had to read alone and had no one to turn to whenever she could not make sense of the course materials. At the minimum, she became lonely and depressed; at the worst, she thought of taking her own life to end it all. This is the essence of the lived experience of the struggling reader with $\mathrm{CP}$ at the university. For her, it had been an experience of an existential crisis in her struggles with reading (Crowell, 2015).

\section{CONCLUSION}

The essence of the phenomenon of the university reading experience of student with CP could be summed up in the following way. First, she lacked the academic literacy needed to successfully navigate through the denser reading materials at university level. Second, the student with CP is regularly confronted with texts that were pitched at frustrational level, and thus had low readability, because they were selected not based on her lack of language proficiency and schemata. Third, she was disadvantaged because of her medical condition and the resultant lack of mobility, all of which caused her to have low self-efficacy, vis a vis her peers who did not have a similar birth defect.

\section{RECOMMENDATIONS}

\section{Reading Support}

Vygotsky (1978) developed the concept of the Zone of Proximal Development (ZPD), which urged educators not to use materials beyond learners' language ceiling. For the student with CP who lacks CALP, her reading challenges would be more serious. She could be provided with the necessary reading support.

\section{Instructional-Level Reading Materials}

University-prescribed reading materials should be at instructional, not frustrational, level (for example, Vygotsky, 1978).

\section{Active Reading}

AR moves the reader beyond rote learning. It implies basic language skills are needed which, in turn, implies the concurrent development of the target language, and development of content knowledge. 


\section{Constructivism}

Lecturers communicate with students, student talk and discuss with each other, questioning and analyzing in the hope of developing a deeper understanding of texts read (Bakhtin, 1981). Access to social reading interaction could be made mandatory.

\section{Reading Motivation}

No one sets out to fail. To minimize the conditions that are likely to eventuate loss of self-efficacy, as well as to improve reading proficiency in the content areas, the recommendation is therefore a) to incorporate language development within content area pedagogy, and b) to provide a sustainable reading support infrastructure for struggling readers.

\section{CONCLUSION}

An estimated 30 percent of those who enroll for university studies are underprepared (Isarji Sarudin et al., 2008). A student with CP needs and expects support in academic literacy, readable materials, and social reading opportunity with course instructors and her peers to keep her motivation to read at optimum level for academic success.

\section{REFERENCES}

Ary, D., Jacobs, L., Razavieh, A., \& Sorenson, C. (2006). Introduction to research in education ( $7^{\text {th }}$ ed.). Belmont, CA: Wadsworth.

Bakhtin, M. M. (1981). The dialogic imagination: Four essays. Edited by Michael Holquist and translated by Caryl Emerson and Michael Holquist. Austin: University of Texas Press.

Blauw-Hospers C. H, Hadders-Algra, M. (2005). A systematic review of the effects of early intervention on motor development. Developmental Medicine and Child Neurology, 47, $421-32$

Blondis T. A. (2004). Neurodevelopmental motor disorders: Cerebral palsy and neuromuscular diseases. In: D. Dewey, D. E. Tupper (Eds.). Developmental motor disorders: A neuropsychological perspective (pp. 113-36. Guilford; New York.

Crowell, S. (2015). "Existentialism", The Stanford Encyclopedia of Philosophy. E. N. Zalta (ed.), Retrieved from https://plato.stanford.edu/archives/spr2015/entries/existentialism/

Isarji Sarudin, Ainol Madziah Zubairi, Mohamed Sahari Nordi \& Mohd Azmi Omar. (2008). The English language proficiency of Malaysian public university students. In Zuraidah Mohd Don, Md Yusof Abu Bakar, Nor Aieni Haji Mokhtar, Rohana Jani, Ainol Madziah Zubairi, Norasma Othman \& Aries Gan (Eds.), Enhancing the quality of higher education through research: Shaping future policy (pp. 40-65). The Ministry of Higher Education, Malaysia.

Kedia S, et al. (2014). Neurologic and muscular disorders. In W. W Hay, Jr. et al., (Eds.). Current diagnosis and treatment: Pediatrics (22nd ed), (pp. 776-861). New York: McGraw-Hill.

Kintsch, W. (2004). The construction-integration model of text comprehension and its implications for instruction. In R. Ruddell \& N. Unrau (Eds.). Theoretical models and processes of reading (pp. 1270-1328). Newark, DE: IRA.

Maxwell, J. A. (2005). Qualitative research design: An interactive approach (2 $\left.{ }^{\text {nd }} e d.\right)$. Thousand Oaks, CA: Sage. 
Mendler, A. N. (2000). Motivating students who don't care: Successful techniques for teachers. Bloomington, IN: National Education Service.

Mokhtari, K. \& Reichard, C. (2002). Assessing students' metacognitive awareness of reading strategies. Journal of Educational Psychology, 94 (2), 249-259.

Moustakas, C. (1994). Phenomenological research methods. Thousand Oaks, CA: Sage.

Reznitskaya, A., Anderson, R. C., \& Kuo, L. J. (2007). Teaching and learning argumentation. Elementary School Journal, 107, 449-472.

Streubert, H. J., \& Carpenter, D. R. (1999). Qualitative research in nursing: advancing the humanistic imperative. ( $2^{\text {nd }}$ ed.), Philadelphia: Lippincott.

van Manen, M. (1990). Researching lived experience: Human science for an action sensitive pedagogy. Albany: State University of New York Press.

Vygotsky, L. S. (1978). Mind in society: The development of higher psychological processes. Cambridge, MA: Harvard University Press.

Walqui and van Lier (2010). Scaffolding the academic success of adolescent English language learners: A pedagogy of promise. San Francisco, California: WestEd.

Wigfield, A., \& Guthrie, J. (1995). Dimensions of children's motivations for reading: An initial study. Reading Research Report No. 34.

Yin, R. (2011). Qualitative research from start to finish. New York: Guilford Press. 